\title{
Tempe and Changes of Cholesterol Pattern in Hyperlipidemic Rabbits
}

\author{
Sri Rahayuningsih ${ }^{\mathrm{a}}$, Suryatmi Retno Dumadi ${ }^{\mathrm{b}}$, Mien Karmini Mahmud ${ }^{\mathrm{c}}$, Nur Asikin $^{\mathrm{d}}$
}

\begin{abstract}
Abstrak
Aterosklerosis dan penyakit jantung koroner diramalkan akan menjadi masalah kesehatan terkemuka di Indonesia. Tingginya kadar lipid darah merupakan faktor resiko yang dapat dikontrol dengan obat dan diet/ pengaturan makanan. Tempe, bahan pangan yang mempunyai nilai gizi ting gi diketahui mengandung zat zat yang dapat mempengaruhi kadar lemak darah. Studi ini mempelajari pengaruh tempe dan faktor 2 , salah satu anti oksidan yang terdapat dalam tempe, terhadap pola kolesterol serum kelinci yang tetap mengkonsumsi kolesterol. Tempe diberikan dalam dosis 6,2 g per kg berat badan per hari. Hasil penelitian ini memperlihatkan bahwa tempe mempunyai kemampuan menahan peningkatan kadar kolesterol darah dan menurunkan kadar kolesterol total sebesar 19,1\%, LDL kolesterol 49,2\%, dan menahan penurunan HDL kolesterol sebesar 25,2, dibanding faktor 2 yang menyebabkan penurunan kolesterol total $18,9 \%, L D L$ kolesterol 40,3\%, dan HDL kolesterol 62\%. Kombinasi tempe dan faktor 2 menyebabkan penurunan kolesterol total 20\%, HDL kolesterol $52,4 \%$, serta meningkatkan LDL kolesterol sebesar 24,5\%. Tampaknya perubahan pola lemak darah terbaik adalah pada kelompok tempe. Pengaruh cara pengolahan ( goreng, kukus, panggang, rebus) pada kemampuan tempe menurunkan lemak darah, dan jumlah yang harus dikonsumsi, perlu dipelajari lebih lanjut, karena yang dikonsumsi manusia adalah bentuk yang sudah diolah.
\end{abstract}

\begin{abstract}
Atherosclerosis and coronary heart disease are predicted to be prominent health problem in the next few years in Indonesia. High blood lipid level is considered to be among the risk factors. It can be controlled by medication and dietary measures. Tempe, a highly nutricious food, is known to contain many substances that could influence blood lipid level. This study was conducted to investigate the influence of tempe, and factor 2, an antioxidant found in tempe, on the blood lipid level of rabbits maintained with a high intake of cholesterol. Tempe was given $6.2 \mathrm{~g} / \mathrm{kg} \mathrm{BW/day.} \mathrm{The} \mathrm{results} \mathrm{of} \mathrm{this} \mathrm{study} \mathrm{shows} \mathrm{that} \mathrm{tempe} \mathrm{inhibit} \mathrm{further} \mathrm{increase} \mathrm{of} \mathrm{cholesterol,} \mathrm{and} \mathrm{decrease} \mathrm{total}$ cholesterol level by $19.1 \%, L D L$ cholesterol by $49.2 \%$, HDL cholesterol by $25,2 \%$. The group receiving factor 2 showed a decrease of total cholesterol by $18.9 \%$, LDL cholesterol for $40.3 \%$ and HDL cholesterol by $62 \%$. The combination of tempe and factor 2 cause a decrease in total cholesterol by $20.2 \%$, HDL cholesterol by $52.4 \%$, but increase the LDL cholesterol by $24.5 \%$. It appeared that tempe gave the best result in changing the blood lipid pattern. Further studies on the effect of ways of cooking (fry, steam, barbeque, boil) to the ability of tempe in decreasing blood lipid level, and the amount/ dosage to be taken is suggested, since those are the forms that are usually consumed.
\end{abstract}

Key words : Tempe, lipid pattern, cholesterol.

\section{INTRODUCTION}

Atherosclerosis and coronary heart disease (CHD) has increased in prevalence in Indonesia. It is predicted that the prevalence will be in the first rank in the year 2000. High blood lipids level is a risk factor in the development of atherosclerosis and CHD. The level of blood lipids can be controlled by drugs and dietary

a Department of Nutrition, Faculty of Medicine University of Indonesia, Jakarta, Indonesia

b Institute for Research and Technology Development (BPPT), Jakarta, Indonesia

c Nutrition Research Centre, Ministry of Health, Bogor, Indonesia

$d$ Department of Biochemistry, Faculty of Medicine, University of Indonesia, Jakarta, Indonesia means. Tempe, a highly nutricious product of soybean, contains several substances i.e. fiber, lecithin, polyunsaturated fatty acids, and isoflavonoids, which are considered to have influences on the level of blood lipids. ${ }^{1-3}$ Fiber, lecithin, and polyunsaturated fatty acids affect the blood cholesterol pattern (total cholesterol, LDL cholesterol, and HDL cholesterol). ${ }^{4-8}$ The isoflavonoids are known to improve capillary permeability, ${ }^{9}$ thereby indirectly reducing the possibility of fat deposition onto the capillary walls. One of the isoflavonoids is factor $2(6,7,4$ 'trihidroxy isoflavone). As a component of tempe, factor 2 might also affect the blood lipid level.

This study was conducted to investigate and to compare the effect of tempe and factor 2 on blood cholesterol and triglycerides in hyperlipidemic rabbits induced by a high cholesterol intake. 


\section{METHODS}

Thirty male rabbits of California strain, aged $5-6$ months and weighing $2-3 \mathrm{~kg}$, were obtained from UPT BPT - HMT Cisarua. They were put in individual cages. Animal chaw was obtained from the Animal Food Laboratory, Faculty of Husbandry, Bogor Institute of Agriculture. Tempe flour was obtained from the Nutrition Research Institute, Bogor, with $6 \%$ water content.

Cholesterol crystal (USP Cholesterin) was the product of Merck no.3670, and palm oil (Vetco, purchased from the market) was used to dissolve the crystal. Factor 2 was kindly donated by Dr. Jha, of the Instituit für Physiologische Chemie, University of Bonn.

Reagents for the determination of total cholesterol, LDL cholesterol, and HDL cholesterol were from Boehringer Mannheim GmBH, Germany.

The experiment was conducted in three periods. The preparatory period was carried out for 30 days to acclimatize the rabbits to the experimental conditions, followed by pre-experimental period (28 days) during which the rabbits were given cholesterol crystal dissolved in palm oil orally to raise the blood lipid level; a significant increase in blood lipid was observed. The daily dosage of $100 \mathrm{mg}$ cholesterol crystal per $\mathrm{kg}$ body weight, and duration of administration was based on preliminary studies using the same strain of rabbits.

In the experimental period ( 21 days) the rabbits were divided into three groups $(n=10)$. The first group was given stock diet plus dried tempe $6.2 \mathrm{~g} / \mathrm{kgBW} /$ day, the second group received stock diet plus factor 2, (23 $\mathrm{mg} / \mathrm{kgBW} /$ day), and the third group received stock diet plus dried tempe and factor 2 . All diets were of equal caloric value. The three groups were maintained high cholesterol intake during pre-experimental and experimental period.

Blood samples were obtained at days 30,58 , and 79 . The body weight was measured at days $0,30,58$, and 79. At the end of each period, total cholesterol, HDL cholesterol, and LDL cholesterol were determined.

Statistical analysis was carried out using Mann whitney and Kruskal Wallis test.

\section{RESULTS}

\section{Preparatory period}

The rabbits were acclimatized to the new environment during this period. Data collected at the end of this period represent the baseline data.
The average body weight at the beginning of this period was $2624.47 \mathrm{~g}(\mathrm{SD}=40.52 \mathrm{~g})$ and increase to 2715.43 $(\mathrm{SD}=40.72 \mathrm{~g})$ at the end of the period. Serum cholesterol level, LDL cholesterol, and HDL cholesterol were, respectively, $74.30 \mathrm{mg} / \mathrm{dL}(\mathrm{SD}=6.38 \mathrm{mg} / \mathrm{dL})$, $39.55 \mathrm{mg} / \mathrm{dL}$ (SD $=5.06 \mathrm{mg} / \mathrm{dL}$ ), and $30.15 \mathrm{mg} / \mathrm{dL}$ (SD $=2.14 \mathrm{mg} / \mathrm{dL}$ ). Due to technical difficulty, serum triglycerides was not determined during this period.

\section{Pre-experimental period}

The pre-experimental period was carried out to bring the rabbits into a hyperlipidemic condition by administering orally a solution of cholesterol crystal in palm oil for 28 days. The results of serum determination and the changes in body weight are presented in Table 1 below.

Table 1. Serum lipids and body weight of rabbits $(n=30)$ at the beginning and at the end of pre-experimental period

\begin{tabular}{lcc}
\hline Parameter & Beginning & End \\
\hline Cholesterol & $76.30(6.38)$ & $252.31(20.82)^{*}$ \\
LDL cholesterol & $39.55(5.06)$ & $116.11(10.13)^{*}$ \\
HDL cholesterol & $30.15(2.14)$ & $70.47(3.33)^{*}$ \\
triglycerides & - & $203.52(20.19)^{*}$ \\
Body weight (g) & $2175.43(40.72)$ & $3000.67(26.67)^{*}$ \\
\hline
\end{tabular}

Concentrations were $\mathrm{mg} / \mathrm{dL}$ ( SEM)

$* \mathrm{p}<0.05$ (Mann Whitney)

\section{Experimental period}

The serum lipid and the changes in body weight during this period can be seen in Table 2. There was no apparent change in the body weight of the rabbits, indicating that the dietary treatment did not have any adverse effect.

Table 2. Serum cholesterol, LDL cholesterol, HDL cholesterol, triglycerides and body weight in 3 groups of rabbits at the start and end of the experimental period

\begin{tabular}{lllllll}
\hline Group & \multicolumn{2}{c}{ Cholest } & \multicolumn{2}{c}{ LDL cholest } & \multicolumn{2}{c}{ HDL cholest } \\
& start & end & start & end & start & end \\
\hline A/Tempe & 261.68 & 211.62 & 111.37 & 56.6 & 60.77 & 45.48 \\
& $(25.84)$ & $(29.7)$ & $(14.96)$ & $(13.66)$ & $(4.65)$ & $(3.17)$ \\
B/Tempe + & 226.62 & 180.82 & 132.36 & 164.76 & 73.39 & 34.93 \\
factor 2 & $(29.35)$ & $(20.70)$ & $(20.57)$ & $(24.04)$ & $(4.3)$ & $(1.12)$ \\
C/Factor 2 & 268.62 & 217.85 & 104.6 & 62.49 & 77.35 & 29.4 \\
& $(50.21)$ & $(26.33)$ & $(17.27)$ & $(14.27)$ & $(7.13)$ & $(6.68)$ \\
\hline
\end{tabular}

Concentrations in $\mathrm{mg} / \mathrm{dL}$ ( SEM) 


\begin{tabular}{lllll}
\hline Group $^{\mathbf{a}}$ & \multicolumn{2}{c}{ Triglycerides (mg/dL) } & \multicolumn{2}{c}{ Body weight } \\
& start & end & start & end \\
\hline A/Tempe & 223.82 & 128.86 & 3035.9 & 3003.0 \\
& $(49.21)$ & $(49.21)$ & $(50.90)$ & $(40.5)$ \\
B/Tempe + & 239.54 & 111.77 & 3004.2 & 2929.0 \\
factor 2 & $(25.37)$ & $(20.01)$ & $(53.09)$ & $(71.23)$ \\
C/Factor 2 & 147.19 & 194.75 & 2961.9 & 2867.0 \\
& $(18.24)$ & $(20.92)$ & $(34.04)$ & $(39.49)$ \\
\hline
\end{tabular}

Significant difference at $p<0.05$ for each parameter, was found before and at the end of experiment, except for body weight.

\section{DISCUSSION}

In the preliminary study, the rabbits were successfully brought into hyperlipidemic condition by daily oral administration, of a solution of $0.2 \%$ cholesterol in palm oil. The increase in serum cholesterol were similar to those reported by Kritchevsky (10), who used a solution of $2 \%$ cholesterol in palm oil to increase serum cholesterol to about $2800 \mathrm{mg} / \mathrm{dL}$. It is apparent that the increase in serum cholesterol was correlated with the amount of cholesterol given. In this case, with $0.2 \%$ cholesterol in the diet, the serum cholesterol was only about $10 \%$ of that given $2 \%$ cholesterol.

The results of this study showed that tempe, given concomitantly with a high cholesterol diet, could inhibit further increase of serum cholesterol, LDL cholesterol, HDL cholesterol, and triglycerides. These findings are in agreement with those of previous investigators, suggesting the presence of substance(s) that could bring a decrease in serum lipid fractions.

Factor 2 also have a similar lowering effect on serum cholesterol fractions. Factor 2 may decrease serum cholesterol through inhibition of the absorption of cholesterol from the intestine, or increasing the excretion of cholesterol through the bile, or decreasing the rate of cholesterol synthesis. Triglycerides, however, was significantly increased in the group receiving Factor 2. Whether factor 2 had no effect in bringing a decrease in serum triglycerides, or adversely increase serum triglycerides, needs further investigation.

The combination of tempe and factor 2 gave a slightly different results. Total cholesterol, HDL cholesterol, and triglycerides were lowered, but LDL cholesterol was increased. The explanation of this discrepancy is not clear. However, the cretically when two substances are given at the same time, there are three possible effects. Firstly, both substances work together, complementing each other in decreasing serum lipid level; secondly, one factor acts as an antagonist to the other; and thirdly, the two substances exhibit no interaction. Factor 2 given alone, result in an increase of serum triglycerides, whereas in combination with tempe, the effect of tempe itself appeared to prevail, thus lowered triglyceride level.

When the pattern of serum lipid changes in the three experimental groups (figure 1) was compared with the normal status, it seems that tempe gave the best result. The decrease in total cholesterol was similar in the three groups, while the decrease in HDL cholesterol ("good" cholesterol) was minimal in the group given tempe alone. In the group receiving tempe, total cholesterol was decreased by $19.1 \%$, LDL cholesterol by $49.2 \%$, triglycerides by $42.4 \%$, and HDL cholesterol by $25.2 \%$. In the group receiving factor 2 , total cholesterol decrease by $18.9 \%$, LDL cholesterol $40 \%$, and HDL cholesterol $62 \%$, with a $32.3 \%$ increase in serum triglyceride. The combination of tempe and factor 2 decrease total cholesterol by $20.2 \%$, triglycerides $53.3 \%$, HDL cholesterol $52.4 \%$, but increase LDL cholesterol by $24.5 \%$.

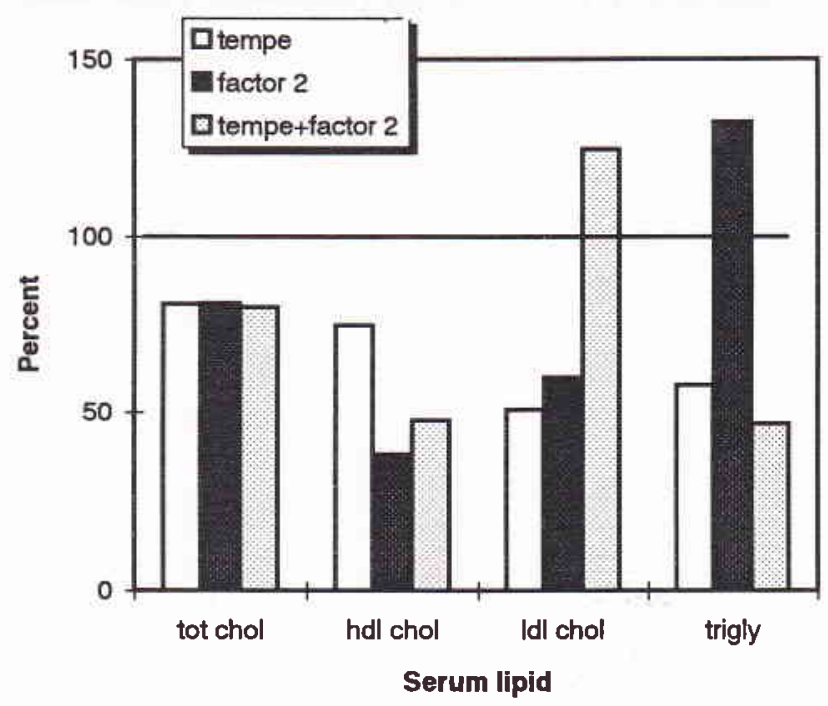

Figure 1. Concentration of serum lipids in 3 groups of rabbits (10 each) given a high cholesterol diet, together with the respective diets for 21 days (see Experimental). The bars indicate the lipid fractions as a percentage of the pretreatment level (solid line).

In conclusion, tempe seems to be a potential food for inhibiting further increase in serum cholesterol, and factor 2 seems to affect the blood lipid profile with yet unknown mechanisms.

Tempe is a popular food in Indonesia, particularly in Java. It is usually consumed with the main course as a protein side dish, a plant protein of high quality. The 
use of tempe as a means of decreasing serum lipid should be introduced and popularized, not only for its relatively inexpensive price, but also for its value as a nutricious food. Further studies are needed to investigate the effects on serum lipid of tempe prepared by a variety of cooking methods, the influence of the amount of tempe consumed, as well as the relationship of the various nutrients present in tempe.

\section{REFERENCES}

1. Murata AK. Antioxidants and vitamins in tempe. In : Simposium Pemanfaatan Tempe dalam Peningkatan Upaya Kesehatan dan Gizi. Puslitbang Gizi, DepKes RI Bogor, 1985.

2. Jha HC. Novel isoflavonoids and its derivatives, new antioxidants derived from fermented soybeans (tempe). In : Asian Symposium on Non-salted Soybean Fermentation. Tsukuba, 1985, pp 199-202.

3. Hartiningsih S, Mangkoewidjojo S, Pramono W. Pengaruh kedelai rebus, tempe dan lemak hewan dalam makanan terhadap kadar cholesterol dalam darah dan skrining fitokimianya. In : Simposium Pemanfaatan Tempe dalam
Peningkatan Upaya Kesehatan dan Gizi. Puslitbang Gizi DepKes RI, Bogor, 1985.

4. Beynen BC, Katan MB. Why do polyunsaturated fatty acids lower serum cholesterol? Am J Clin Nutr 1985; 42: 560 - 3.

5. Anderson JW, Story L, Sieling B, et al. Hypocholesterolemic effects of oat bran or bean intake for hypercholesterolemic men. Am J Clin Nutr 1984; 40: 1146 - 55.

6. Glenn JL, Dam H. Influence of dietary lipids on the fatty acid composition of neutral lipids and phosphatides in chick liver and bile. J Nutr 1965; 86: 143 - 52.

7. Kesaniemi YA, Grundy SM. Effect of dietary polyenilphosphatidylcholine on metabolism of cholesterol and triglycerides in hypertriglyceridemia patients. Am J Clin Nutr 1986; 43: 98-107.

8. William PT, Krauss RM, Joyce SK, et al. Relation of dietary fat, protein, cholesterol, and fiber intake to atherogenic lipoproteins in man. Am J Clin Nutr 1986; 44: 792.

9. Robbins C. Physiology and functions of flavonoids - Pharmacological and clinical application. In : The Flavonoids. Harbome JB, ed. Chapman and Hall, London 1974: 791.

10. Kritchevsky D. Role of cholesterol vehicle in experimental atheroscerosis. 1970. In : The Biology of the Laboratory Rabbits. Weisbroth SH, Flatt RE, Kraus AL, eds. Academic Press, New York and London, 1974 :156. 